\title{
Genetic parameters for conception rate and milk production traits within and across Holstein herds with different housing types and feeding systems during the first 3 lactations
}

\author{
T. Yamazaki, ${ }^{1 *}$ (1) S. Yamaguchi, ${ }^{2} \odot$ H. Takeda, ${ }^{3} \odot$ T. Osawa, ${ }^{4}{ }^{\oplus}$ and K. Hagiya ${ }^{5} \odot$ \\ ${ }^{1}$ Hokkaido Agricultural Research Center, National Agriculture and Food Research Organization (NARO), Sapporo, 062-8555, Japan \\ ${ }^{2}$ Hokkaido Dairy Milk Recording and Testing Association, Sapporo, 060-0004, Japan \\ ${ }^{3}$ Institute of Livestock and Grassland Science, NARO, Tsukuba, 305-0901, Japan \\ ${ }^{4}$ National Livestock Breeding Center, Fukushima, 961-8511, Japan \\ ${ }^{5}$ Obihiro University of Agriculture and Veterinary Medicine, Obihiro, 080-8555, Japan
}

\begin{abstract}
The housing types (HST) in which dairy cows are kept and the feeding systems (FDS) used differ among farmers in Japan. Here, we investigated the genetic relationships among conception rate at first insemination (CR) and milk production traits (PROD) during the first 3 lactations of Holstein cows by using a multipletrait model that considered the trait values of herds with different HST [tiestall (TSL) barn, freestall (FS) barn, or grazing (GZ)] and FDS as separate traits. Milk production and conception records of Holstein cows in the Hokkaido region of Japan (283,611 records for first lactation, 253,902 for second, and 181,197 for third) were analyzed. We categorized herds with TSL or FS into 2 types of FDS for cows: separate feeding (SF) of roughage plus concentrate or feeding of total mixed ration, in which roughage and concentrates were mixed before feeding. The PROD analyzed were cumulative milk, fat, and protein yields within $305 \mathrm{~d}$ and lactation persistency, which we defined as the difference between milk yields at 240 and $60 \mathrm{~d}$ in milk. We estimated the heritabilities for CR or PROD within each HST or HST $\times$ FDS group and the genetic correlations between these traits within each group or across different groups within each lactation by using a 3-HST (TSL, FS, and GZ) $\times 2$-trait $(\mathrm{CR}$ and each PROD) or 2-HST (TSL and FS $) \times 2$-FDS $\times 2$-trait animal model. Heritability estimates for CR in GZ were higher than those in TSL or FS, and genetic correlations for CR between GZ and TSL or FS barns were weaker than those between TSL and FS barns. In addition, genetic correlations between CR and PROD in GZ were weaker than those in TSL and FS barns. In the comparison among the 4 HST $\times$ FDS except GZ, heritability estimates for
\end{abstract}

Received March 10, 2020.

Accepted June 6, 2020.

*Corresponding author: yamazakt@affrc.go.jp
$\mathrm{CR}$ in $\mathrm{FS} \times \mathrm{SF}$ were higher than those in the others, and genetic correlations for $\mathrm{CR}$ between $\mathrm{FS} \times \mathrm{SF}$ and the other systems were relatively weak. These results indicated that differences in the production system for Holstein cows influence genotypic effects in terms of the cows' ability to conceive and the genetic relationships between fertility traits and milk production traits.

Key words: conception rate, dairy cattle, genotype by environment interaction, management system

\section{INTRODUCTION}

Several types of management systems are used on Japanese dairy farms. Traditionally, dairy cows in Japan have been kept in tiestall (TSL) barns, and herds have been small. However, the number of dairy farms using freestall (FS) barns instead of TSL has been increasing, and farms managing dairy cows mainly through pasture grazing $(\mathbf{G Z})$ remain less common than those using TSL or FS barns because grazing during the winter is impractical in most regions of Japan. Several factors, including herd size, the amount of pastureland, and the mainly available roughage, influence which housing type (HST) is used. In addition, the feeding systems (FDS) typically used on dairy farms in Japan are separate feeding (SF), in which roughage and concentrates are weighed and fed individually to each cow, and feeding of a TMR, in which roughage and concentrates are mixed. In the SF system, the proportions of roughage and concentrates can differ among cows. In TMR feeding, feeding processes are simplified, and roughage-concentrates balances are the same among the cows in each herd. The SF and TMR feeding systems are often used in TSL and FS barns, respectively.

Whether a genotype by environment interaction $(\mathbf{G}$ $\times \mathbf{E})$ affects a particular trait of dairy cattle can be examined by considering various environmental descriptors, such as region, herd size, temperature-humidity 
index, herd-average production, and management system (e.g., Boettcher et al., 2003; Calus et al., 2005; Haile-Mariam et al., 2008). Low genetic correlations among environmental descriptors mean that $\mathrm{G} \times \mathrm{E}$ has a large effect, such as the $\mathrm{G} \times \mathrm{E}$ effect on female fertility in dairy cattle (e.g., Strandberg et al., 2009; Ismael et al., 2016; Liu et al., 2019).

Although some $\mathrm{G} \times \mathrm{E}$ interactions on fertility traits have been examined in regard to herd management systems (Boettcher et al., 2003; Liu et al., 2019), to our knowledge, no previous study has assessed the combined influence of HST and FDS systems on these traits. Furthermore, the genetic correlations among fertility traits and milk production traits under various HST $\times$ FDS have not yet been studied. Farmers need this information regarding genetic relationships in different production systems so that they choose the bulls with the most appropriate breeding values for each trait to improve their cows' productivity.

Our objective here was to investigate the genetic relationships among fertility traits and milk production traits during the first 3 lactations of Holstein cows. To this end, we used a multiple-trait model that considered the trait values of herds with different HST $\times$ FDS as separate traits. The female fertility trait that we used was conception rate at first insemination (CR).

\section{MATERIALS AND METHODS}

\section{Data}

We obtained insemination records and monthly testday milk records within 305 DIM during the first 3 lactations of Holstein cows that had calved between 2008 and 2014 and had first insemination records from 21 to 200 DIM from the Hokkaido Dairy Milk Recording and Testing Association (Sapporo, Japan); these records were collected through the DHI program. Age at first insemination ranged from 20 through 46 mo at the first lactation (for second calving), from 32 through 66 mo at the second, and from 44 through 86 mo at the third. The minimum size of the contemporary groups (herd-year for first insemination and that for calving) was 3 cows for each data set. Each cow had at least 8 test-day records.

Records of HST and FDS for each herd were obtained from farmers' responses to surveys of their cow management systems; these surveys were conducted in 2012 in the Hokkaido region. We used these results to categorize herds with data into 3 groups of HST (TSL barn, FS barn, and GZ except in winter) and 2 groups of FDS (SF and TMR). Records of herds that changed HST or FDS since 2008 were removed from the analysis. The total numbers of cows with records for the first, second, and third lactations were 283,611, 253,902, and 181,197, respectively. The numbers of records and herds in each HST $\times$ FDS group are shown in Table 1 . The GZ herds were not categorized according to FDS, owing to the few herds in this group. The numbers of sires in each group and the common sires between 2 groups of HST and HST $\times$ FDS are shown in Tables 2 and 3, respectively. At least $97 \%$ of sires in GZ were also used in TSL and FS.

The female fertility trait used was CR, where CR $=1$ indicated that the first insemination achieved pregnancy, and 0 indicated otherwise. Milk production traits (PROD) used were cumulative milk (milk), fat (fat), and protein (PRO) yields within 305 DIM and lactation persistency. Lactation persistency was defined as the difference between milk yields at 240 and 60 DIM (Yamazaki et al., 2014). The PROD were estimated by using multiple-trait prediction (Schaeffer and Jamrozik, 1996) according to Wilmink's function (Wilmink, 1987). Summary statistics of each trait for the $3 \mathrm{HST}$ and $4 \mathrm{HST} \times$ FDS $(2$-HST $\times 2$-FDS $)$ groups are shown in Figures 1 and 2, respectively.

Table 1. Numbers of cows and herds in each housing type (HST) and feeding system (FDS) for the first 3 lactations $^{1}$

\begin{tabular}{|c|c|c|c|c|c|c|}
\hline \multirow[b]{3}{*}{ Item } & \multirow[b]{3}{*}{ Lactation } & \multicolumn{5}{|c|}{ HST and FDS } \\
\hline & & \multicolumn{2}{|c|}{ TSL } & \multicolumn{2}{|c|}{ FS } & \multirow[b]{2}{*}{$\mathrm{GZ}$} \\
\hline & & $\mathrm{SF}$ & TMR & $\mathrm{SF}$ & TMR & \\
\hline \multirow[t]{3}{*}{ Number of cows } & First & 90,066 & 34,121 & 18,884 & 134,203 & 6,337 \\
\hline & Second & 85,472 & 31,111 & 16.323 & 114.648 & 6.348 \\
\hline & Third & 64,996 & 22,380 & 11,499 & 77,400 & 4,922 \\
\hline \multirow[t]{3}{*}{ Number of herds } & First & 1,604 & 431 & 134 & 683 & 100 \\
\hline & Second & 1.614 & 431 & 134 & 686 & 100 \\
\hline & Third & 1,595 & 432 & 133 & 685 & 101 \\
\hline
\end{tabular}

${ }^{1}$ The HST groups are tiestall barn (TSL), freestall barn (FS), and management primarily by grazing on pasture (GZ). The FDS groups are separate feeding (SF), in which roughage and concentrates were weighed and fed separately, and feeding of TMR, in which roughage and concentrates were mixed before feeding. 
Table 2. Numbers of sires (on the diagonal) in each housing type (HST) and of sires in common (above the diagonal) between 2 HST for the first 3 lactations ${ }^{1}$

\begin{tabular}{llccc}
\hline & & \multicolumn{3}{c}{ HST } \\
\cline { 3 - 5 } Lactation & HST & TSL & FS & GZ \\
\hline First & TSL & 2,262 & 2,083 & 693 \\
& FS & & 2,348 & 695 \\
\multirow{2}{*}{ Second } & GZ & & & 712 \\
& TSL & 2,343 & 2,119 & 726 \\
\multirow{2}{*}{ Third } & FS & & 2,392 & 731 \\
& GZ & & & 751 \\
& TSL & 2,295 & 2,028 & 639 \\
& FS & & 2,285 & 626 \\
& GZ & & & 659 \\
\hline
\end{tabular}

${ }^{1}$ The HST groups are tiestall barn (TSL), freestall barn (FS), and management primarily by grazing on pasture (GZ).

\section{Models}

Data were analyzed within each lactation by using 2-trait (CR and each PROD) linear models that took into account the genetic covariance among records for 3 HST (model_HST) or 4 HST $\times$ FDS groups (model_ $\mathrm{HST} \times \mathrm{FDS})$. The model used for $\mathrm{CR}$ was

$y_{i j k l m n o}=F H Y_{i}+F M_{j}+F A_{k}+F D I M_{l}+s_{m}+u_{n o}+e_{i j k l m n o}$,

where $y_{i j k l m n o}$ is the $\mathrm{CR}$ of cow $o ; F H Y_{i}$ is the fixed effect of herd-year $i$ for first insemination (the levels in model_HST and model_HST $\times$ FDS, respectively, were 17,419 and 16,850 for the first lactation, 19,036 and 18,379 for the second, and 18,190 and 17,567 for the third); $F M_{j}$ is the fixed effect of month $j$ at first insemination; $F A_{k}$ is the fixed effect of age group $k$ at first insemination with 7 levels $(18,19,20,21$ through
25, 26 through 30, 31 through 40, and $\geq 41 \mathrm{mo}$ ); FDIM is the fixed effect of DIM group $l$ at first insemination that was created by subdividing the overall range of DIM into consecutive 10-d intervals (18 levels: 21 through 30, 31 through 40, .,, 181 through 190, and 191 through $200 \mathrm{~d}) ; s_{m}$ is the random effect of service sire $m$ at first insemination (the numbers of service sires in model_HST and model_HST $\times$ FDS, respectively, were 2,990 and 2,978 for the first lactation, 3,010 and 3,002 for the second, and 2,923 and 2,911 for the third); $u_{n o}$ is HST or HST $\times$ FDS group $n \times$ the random additive effect of animal $o$; and $e_{i j k l m n o}$ is a random residual effect associated with $y_{i j k l m n o}$. The age effect at first insemination was not considered for the third lactation record.

The model for PROD was

$$
y_{i j k n o}=H Y_{i}+M_{j}+A_{k}+u_{n o}+e_{i j k n o},
$$

where $y_{i j k n o}$ is PROD of cow $o ; H Y_{i}$ is the fixed effect of herd-year $i$ for calving (the levels in model_HST and model_HST $\times$ FDS, respectively, were 17,121 and 16,551 for the first lactation, 18,570 and 17,923 for the second, and 17,694 and 17,083 for the third); $M_{j}$ is the fixed effect of calving month $j ; A_{k}$ is the fixed effect of calving age group $k$, with 30 levels (18 through 20, 21 through $22,23,24,25,26,27,28,29,30,31,32,33$, 34 , and $\geq 35$ mo for first lactation; $\leq 35,36$ through 37, 38 through 39,40 through 41,42 through 43,44 through 45,46 through 47,48 through 49 , and $\geq 50$ mo for second lactation; and $\leq 45,46$ through 50, 51 through 55,56 through 60,61 through 65 , and $>66$ mo for third lactation); and $u_{n o}$ and $e_{i j k n o}$ are defined as in the previous model. The pedigree was traced back 5

Table 3. Numbers of sires (on the diagonal) in each housing type (HST) and feeding system (FDS) and of sires in common (above the diagonal) between 2 HST $\times$ FDS for the first 3 lactations ${ }^{1}$

\begin{tabular}{|c|c|c|c|c|c|}
\hline \multirow[b]{2}{*}{ Lactation } & & \multicolumn{4}{|c|}{$\mathrm{HST} \times \mathrm{FDS}$} \\
\hline & & $\mathrm{TSL} \times \mathrm{SF}$ & $\mathrm{TSL} \times \mathrm{TMR}$ & $\mathrm{FS} \times \mathrm{SF}$ & $\mathrm{FS} \times \mathrm{TMR}$ \\
\hline \multirow[t]{4}{*}{ First } & $\mathrm{TSL} \times \mathrm{SF}$ & 2,151 & 1,624 & 1,234 & 1,984 \\
\hline & $\mathrm{TSL} \times \mathrm{TMR}$ & & 1,735 & 1,092 & 1,648 \\
\hline & $\mathrm{FS} \times \mathrm{SF}$ & & & 1,317 & 1,262 \\
\hline & $\mathrm{FS} \times \mathrm{TMR}$ & & & & 2,293 \\
\hline \multirow[t]{4}{*}{ Second } & $\mathrm{TSL} \times \mathrm{SF}$ & 2,217 & 1,629 & 1,194 & 2,024 \\
\hline & $\mathrm{TSL} \times \mathrm{TMR}$ & & 1,755 & 1,038 & 1,651 \\
\hline & $\mathrm{FS} \times \mathrm{SF}$ & & & 1,269 & 1,217 \\
\hline & $\mathrm{FS} \times \mathrm{TMR}$ & & & & 2,340 \\
\hline \multirow[t]{4}{*}{ Third } & $\mathrm{TSL} \times \mathrm{SF}$ & 2,160 & 1,400 & 1,041 & 1,916 \\
\hline & $\mathrm{TSL} \times \mathrm{TMR}$ & & 1,535 & 839 & 1,409 \\
\hline & $\mathrm{FS} \times \mathrm{SF}$ & & & 1,116 & 1,053 \\
\hline & $\mathrm{FS} \times \mathrm{TMR}$ & & & & 2,222 \\
\hline
\end{tabular}

${ }^{1}$ The HST groups are tiestall barn (TSL) and freestall barn (FS). The FDS groups are separate feeding (SF), in which roughage and concentrates were weighed and fed separately, and feeding of TMR, in which roughage and concentrates were mixed before feeding. 
First lactation

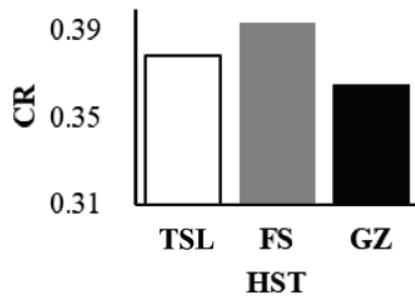

First lactation

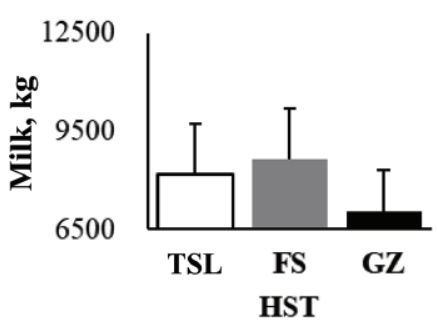

First lactation

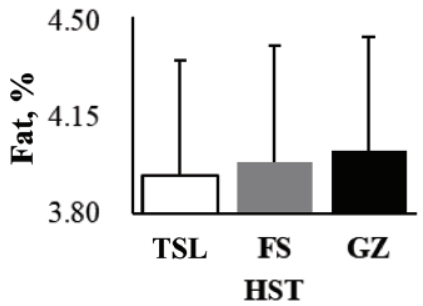

First lactation

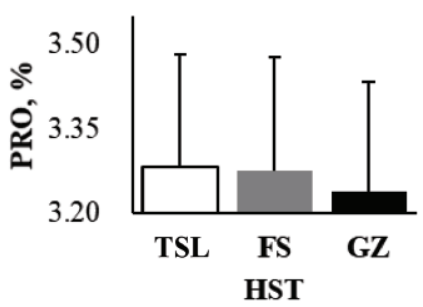

First lactation

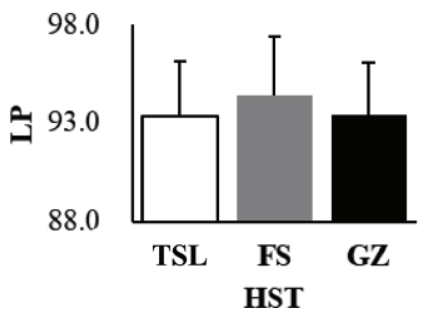

Second lactation

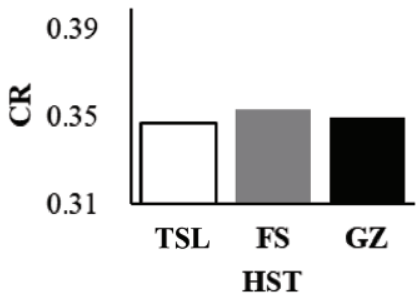

Second lactation

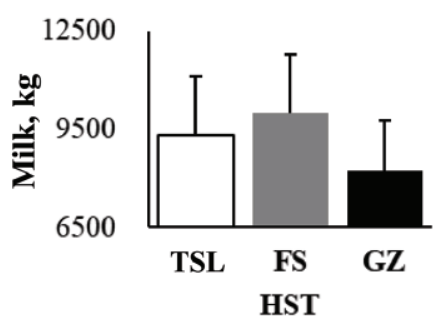

Second lactation

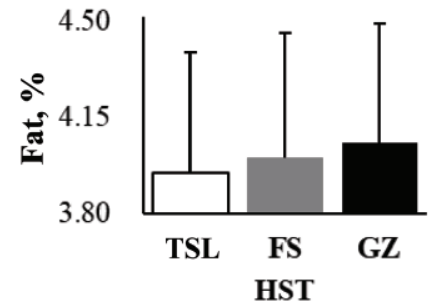

Second lactation

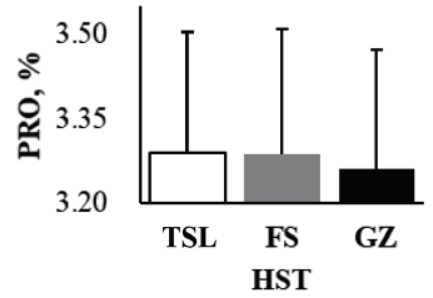

Second lactation

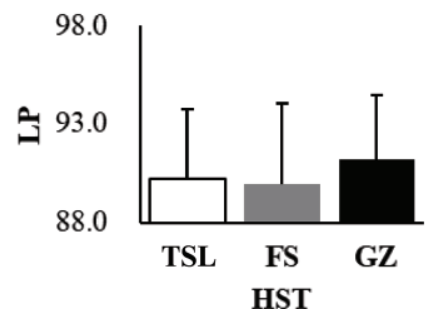

Third lactation

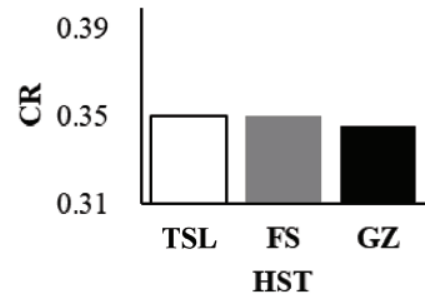

Third lactation

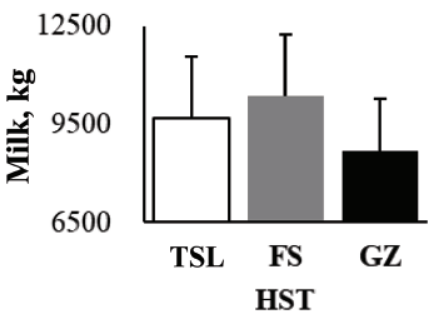

Third lactation

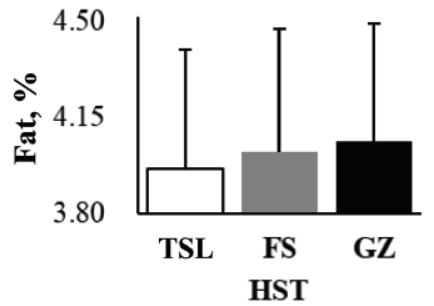

Third lactation

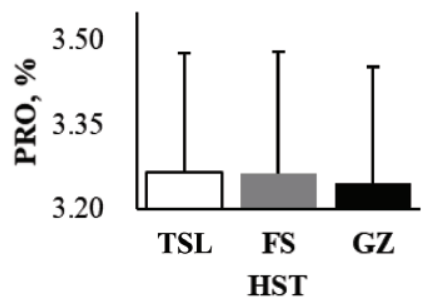

Third lactation

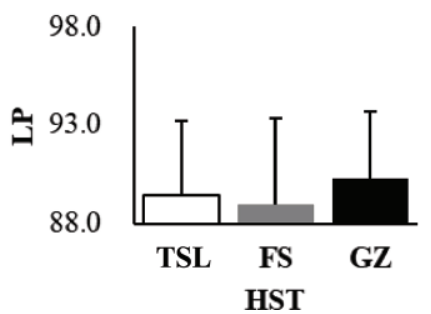

Figure 1. Summary statistics of conception rate at first insemination (CR) and milk production traits in each housing type (HST) for the first 3 lactations. The production traits are cumulative milk, fat, and protein (PRO) yields within 305 DIM and lactation persistency (LP). LP $=100+$ milk yield at 240 DIM - milk yield at 60 DIM. Fat and PRO were analyzed as yield traits, although this figure shows percentages for these traits. The HST groups are tiestall barn (TSL), freestall barn (FS), and management primarily by grazing on pasture (GZ). Error bars represent SD. 
First lactation

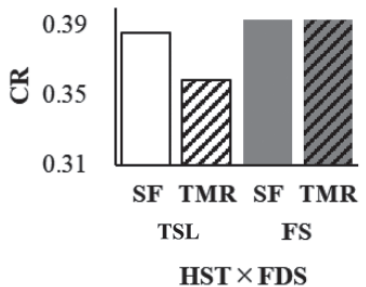

First lactation

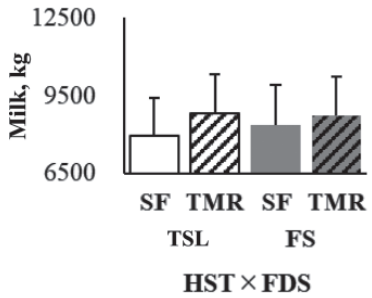

First lactation

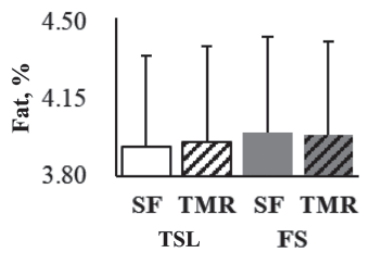

HST $\times$ FDS

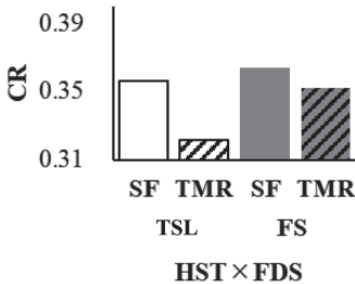

Second lactation

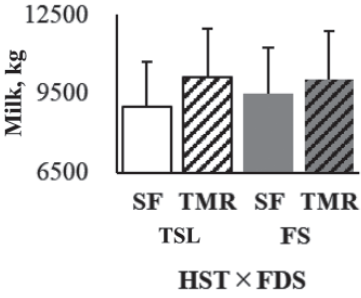

Second lactation

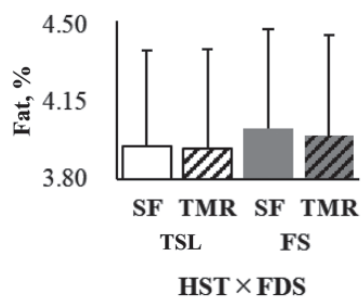

Second lactation

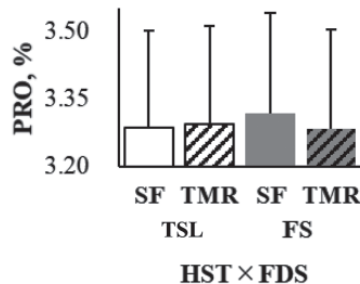

Second lactation

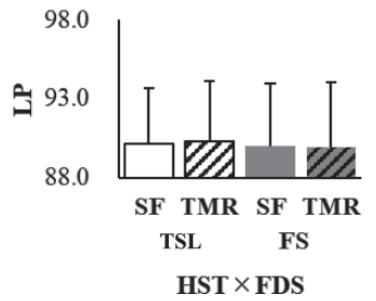

Third lactation

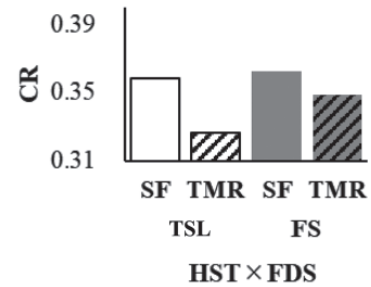

Third lactation

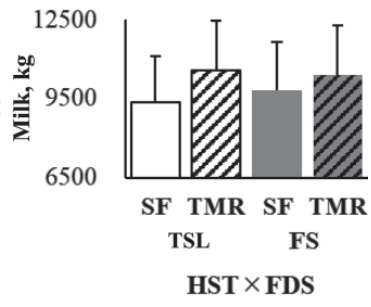

Third lactation

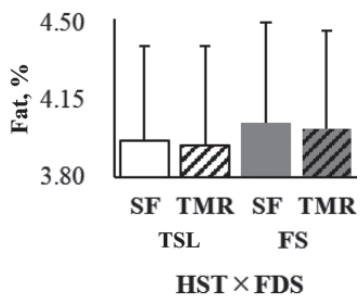

Third lactation

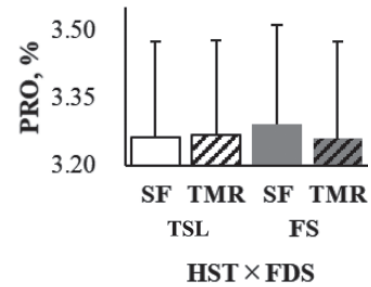

Third lactation

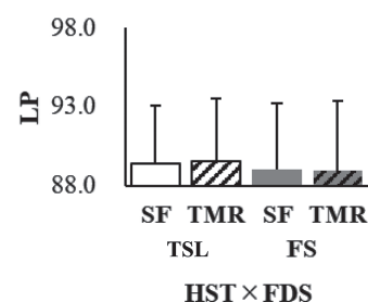

Figure 2. Summary statistics of conception rate at first insemination (CR) and milk production traits in each housing type (HST) and feeding system (FDS) for the first 3 lactations. The production traits are cumulative milk, fat, and protein (PRO) yields within 305 DIM and lactation persistency (LP). LP $=100+$ milk yield at 240 DIM - milk yield at 60 DIM. Fat and PRO were analyzed as yield traits, although this figure shows percentages for these traits. The HST groups are tiestall barn (TSL) and freestall barn (FS). The FDS groups are separate feeding (SF), in which roughage and concentrates were weighed and fed separately, and feeding of TMR, in which roughage and concentrates were mixed before feeding. Error bars represent SD. 


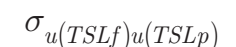

$$
\sigma_{u(F S p)^{2}}
$$$$
\sigma_{u(F S p) u(G Z f)}
$$

Symmetric

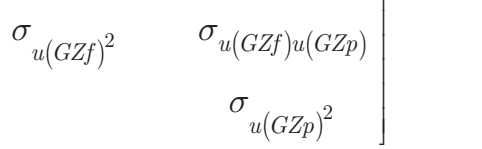

$$
\mathbf{R}=\left[\begin{array}{cccccc}
\sigma_{e(T S L f)} & \sigma_{e(T S L f) e(T S L p)} & 0 & 0 & 0 & 0 \\
& \sigma_{e(T S L p)} & 0 & 0 & 0 & 0 \\
& & \sigma_{e(F S f)^{2}} & \sigma_{e(F S f) e(F S p)} & 0 & 0 \\
& & & \sigma_{e(F S p)^{2}} & 0 & 0 \\
& & & & \sigma_{e(G Z f)^{2}} & \sigma_{e(G Z f) e(G Z p)} \\
& & & & & \sigma_{e(G Z p)^{2}}
\end{array}\right],
$$

generations for each data set and included from 482,641 to 668,195 animals.

The covariance structure was defined as

$$
\operatorname{Var}\left[\begin{array}{l}
s \\
u \\
e
\end{array}\right]=\left[\begin{array}{ccc}
\mathbf{S} \otimes \mathbf{I} & 0 & 0 \\
0 & \mathbf{G} \otimes \mathbf{A} & 0 \\
0 & 0 & \mathbf{R} \otimes \mathbf{I}
\end{array}\right] .
$$

For example, for model_HST,

$$
\mathbf{S}=\left[\begin{array}{ll}
\sigma_{s}^{2} & 0 \\
0 & 0
\end{array}\right]
$$

and the equations for $\mathbf{G}$ and $\mathbf{R}$ are given above, where $s, u$, and $e$ are vectors of service sire effects for first insemination, additive genetic effects, and residual effects, respectively; $\mathbf{S}$ is a (co)variance matrix of random service sire effects for first insemination; $\mathbf{G}$ is a (co)variance matrix of random additive genetic effects; $\mathbf{R}$ is a residual (co)variance matrix; $\mathbf{A}$ is the additive genetic relationship for animals; $\mathbf{I}$ is the identity matrix; subscripts [TSLf (or TSLp)], [FSf (or FSp)], and $[G Z f$ (or $G Z p)]$ are CR (or PROD) for TSL, FS, and GZ, respectively; and $\otimes$ indicates the Kronecker product. The residual covariances between different HST were fixed to zero. The GIBBS3F90 program (Misztal, 2008) was used for Gibbs sampling to estimate the vari- ance components. For Gibbs sampling, the first 300,000 samples were discarded as burn-in. The subsequent 200,000 samples were saved to calculate posterior means and standard deviations for (co)variance components. The convergence was verified through the inspection of graphical data by using the postgibbsf90 program (Misztal, 2008).

\section{RESULTS}

In our data set, TSL $\times$ SF farms were the most common, accounting for $54 \%$ of all farms (Table 1). However, the numbers of cows kept on FS $\times$ TMR systems were the highest, accounting for $47 \%, 45 \%$, and $43 \%$, respectively, of all of first-, second-, and third-lactation cows. The average number of first-lactation cows per TSL, FS, and GZ farm was 61, 187, and 63, respectively; the herd size on FS farms was approximately 3 times those on TSL and GZ farms.

Among the 3 HST systems, CR for the first lactation was highest in FS (0.393) and lowest in the GZ system (0.365; Figure 1); CR showed only minor differences among HST in the second and third lactations. For all lactations, the averages of milk were highest in the FS system and lowest in GZ. In the HST (TSL or FS) $\times$ FDS $(\mathrm{SF}$ or TMR) groups, $\mathrm{CR}$ in the TSL $\times$ TMR system were the lowest in all lactations (Figure 2); the values for the first, second, and third lactations were $0.359,0.322$, and 0.326 , respectively. The averages of 
milk in TMR systems were higher than those in SF and those in TSL $\times$ SF were lowest in all lactations.

\section{Heritabilities of Each HST or HST $\times$ FDS}

Regarding the results estimated by using model_ HST, the heritability estimates for CR in GZ systems were significantly $(P<0.05)$ higher than those in the TSL and FS systems in all lactations (Figure 3); the heritability values in GZ rose with increasing lactation number. The heritabilities for milk and PRO did not differ significantly among HST systems. However, the heritability for fat in GZ was significantly lower than that in TSL and FS in the first lactation, and that for LP was significantly higher in the FS system than in TSL and GZ in the second lactation.

When we used model_HST $\times$ FDS, the heritability estimates for $\mathrm{CR}$ in the FS $\times \mathrm{SF}$ system were significantly higher $(P<0.05)$ than those in TSL $\times \mathrm{SF}$ and FS $\times$ TMR in the first lactation, than those in TSL $\times$ $\mathrm{SF}$ and FS $\times$ TMR in the second lactation, and than those in TSL $\times$ SF and TSL $\times$ TMR in the third lactation (Figure 4). Furthermore, the heritability for CR in TSL $\times$ TMR was significantly higher than that in TSL $\times \mathrm{SF}$ and FS $\times$ TMR in the second lactation.

The heritability for milk was significantly lower in FS $\times$ SF than in TSL $\times$ TMR in the second lactation. The heritability for fat in FS $\times$ SF was significantly lower than in all other HST $\times$ FDS in the second lactation (Figure 4). The PRO heritability in TSL $\times$ SF was significantly lower than that in TSL $\times$ TMR and FS $\times$ TMR in the first lactation, and than that in FS $\times$ TMR in the second and third lactations. The heritability for LP in TSL $\times$ SF was significantly lower than that in FS $\times$ TMR in the third lactation.

\section{Genetic Correlations Between CR and PROD Within Each HST or HST $\times$ FDS}

According to model_HST, the genetic correlations between CR and PROD were weak and negative in TSL or FS systems, and most of those in GZ were weaker than those in TSL or FS (Table 4). The genetic correlations between $\mathrm{CR}$ and milk in GZ systems were significantly smaller than those in TSL and FS in all lactations, except in FS in the second lactation. The genetic correlations of $\mathrm{CR}$ with fat in GZ systems were significantly smaller than the correlation in the TSL system in the first lactation and the correlation in the FS system in the third lactation. The genetic correlations of CR with PRO in GZ were significantly smaller than those in the other HST systems in the first lactation and than the correlation in the FS system in the third lactation. The genetic correlations between CR and LP did not differ significantly among HST systems in all lactations, except for the significant difference between TSL (-0.273) and GZ (0.111) in the second lactation.

In the results estimated by using model_HST $\times$ FDS, the genetic correlations between $\mathrm{CR}$ and PROD in the TSL $\times$ SF systems in the first and second lactations were stronger than those in all other HST $\times$ FDS, except for the genetic correlations between CR and PRO in the second lactation (Table 5); the correlations of $\mathrm{CR}$ with milk, fat, and PRO in TSL $\times \mathrm{SF}$ systems in the first lactation were significantly greater than those in TSL $\times$ TMR or FS $\times$ TMR. The genetic correlation between $\mathrm{CR}$ and PRO in the TSL $\times$ TMR system was significantly greater than the correlations in $\mathrm{FS} \times \mathrm{SF}$ or FS $\times$ TMR in the second lactation. The genetic correlations between $\mathrm{CR}$ and LP did not differ significantly among HST $\times$ FDS in any lactation.

\section{Genetic Correlations of Each Trait Across Different HST or HST $\times$ FDS}

Under model_HST, the genetic correlations of CR between GZ and the other HST were weaker than those between TSL and FS in all lactations (Table 6). The genetic correlations of CR for TSL-GZ and FS-GZ in the first lactation, the correlation for FS-GZ in the second lactation, and the correlation for TSL-GZ in the third lactation were significantly smaller than those for TSL-FS in each lactation. In addition, the genetic correlations of PROD for FS-GZ were weaker than those for TSL-FS; in particular, significant differences were observed for milk in the second lactation, fat in the third lactation, and PRO in the first and third lactations. Furthermore, the genetic correlations of LP for TSL-GZ and FS-GZ were significantly smaller than the correlation for TSL-FS in the second lactation. In the third lactation, the genetic correlation of LP for FS-GZ was significantly smaller than that for TSL-FS.

According to the results from model_HST $\times$ FDS, the genetic correlations of $\mathrm{CR}$ between $\mathrm{FS} \times \mathrm{SF}$ and all other HST $\times$ FDS were weaker than those across the other HST $\times$ FDS pairs in the same lactation (Table 7). The genetic correlations of $\mathrm{CR}$ for $\mathrm{FS} \times \mathrm{SF}-\mathrm{TSL}$ $\times$ TMR in the first lactation were significantly smaller than those for TSL $\times$ SF-TSL $\times$ TMR or TSL $\times$ SFFS $\times$ TMR; in the second lactation the correlations of $\mathrm{CR}$ for $\mathrm{FS} \times \mathrm{SF}$-the other HST $\times$ FDS were significantly smaller than that for TSL $\times$ SF-TSL $\times$ TMR. In the third lactation, the correlation of CR for FS $\times$ SF-FS $\times$ TMR was significantly smaller than those for $\mathrm{TSL} \times \mathrm{SF}-\mathrm{TSL} \times \mathrm{TMR}$ and TSL $\times \mathrm{SF}-\mathrm{FS} \times \mathrm{TMR} . \mathrm{In}$ addition, the genetic correlation of LP for FS $\times$ SF-FS $\times$ TMR was significantly smaller than those for TSL 
First lactation

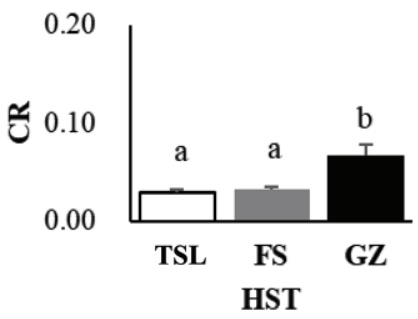

First lactation

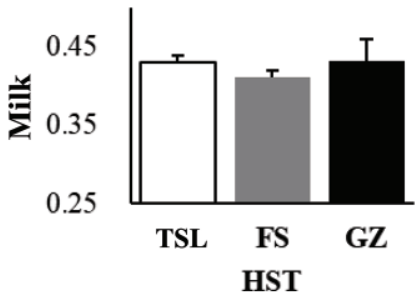

First lactation

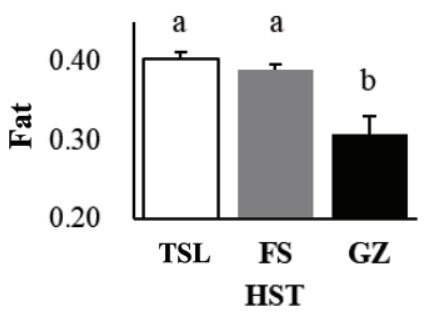

First lactation

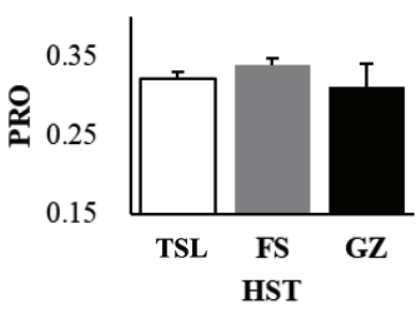

First lactation

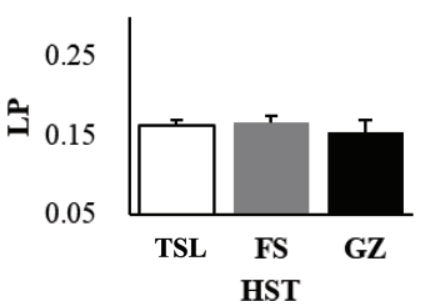

Second lactation

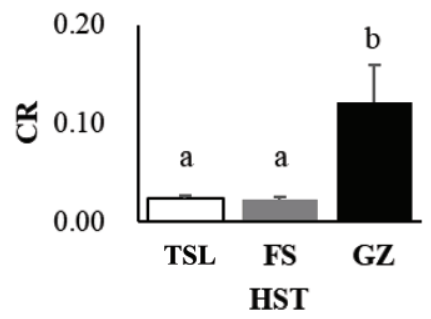

Second lactation

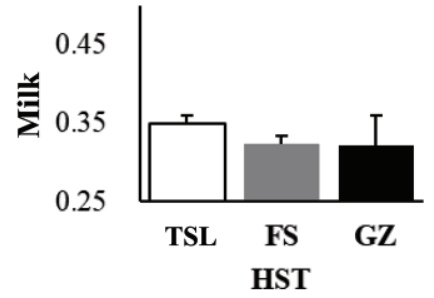

Second lactation

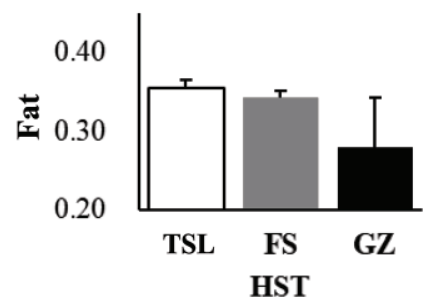

Second lactation

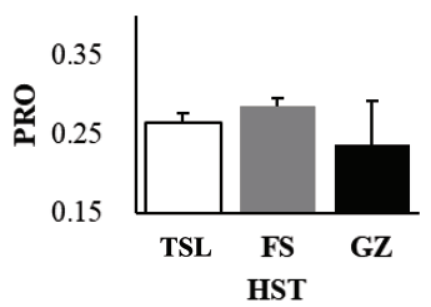

Second lactation

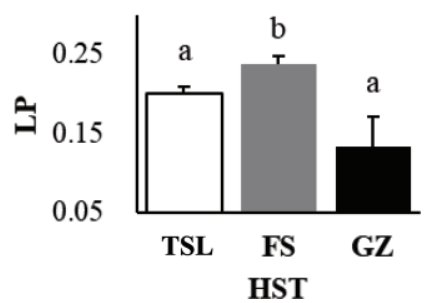

Third lactation

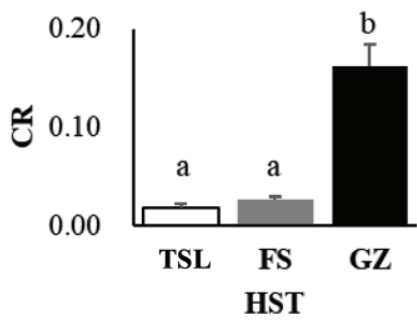

Third lactation

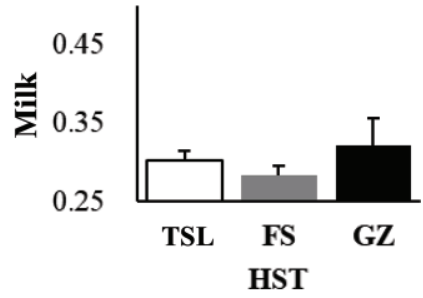

Third lactation

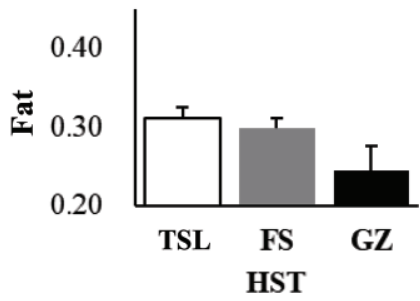

Third lactation

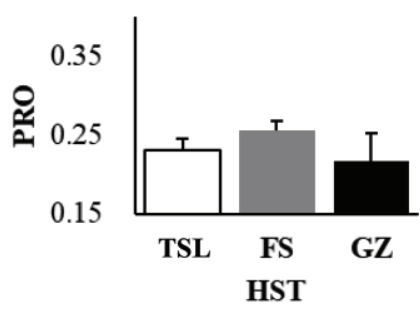

Third lactation

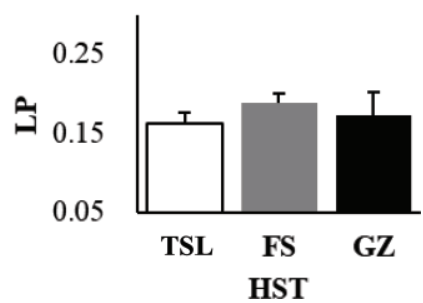

Figure 3. Posterior means of heritability for conception rate at first insemination (CR) and milk production traits in each housing type (HST) for the first 3 lactations. Within each figure, values with different letters (a, b) differ significantly $(P<0.05$ after Bonferroni correction). The production traits are cumulative milk, fat, and protein $(\mathrm{PRO})$ yields within 305 DIM and lactation persistency $(\mathrm{LP})$. LP $=100+$ milk yield at 240 DIM - milk yield at 60 DIM. The HST groups are tiestall barn (TSL), freestall barn (FS), and management primarily by grazing on pasture (GZ). Error bars represent posterior SD. 
First lactation

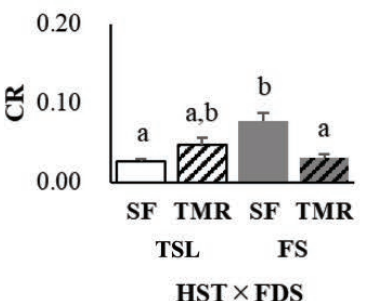

First lactation

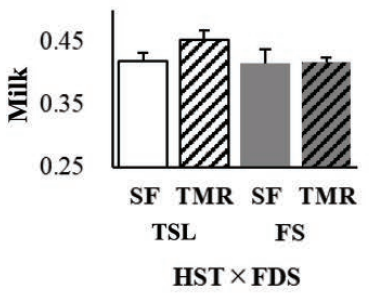

First lactation

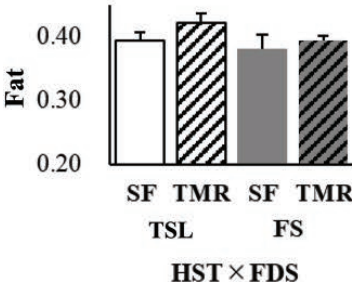

First lactation

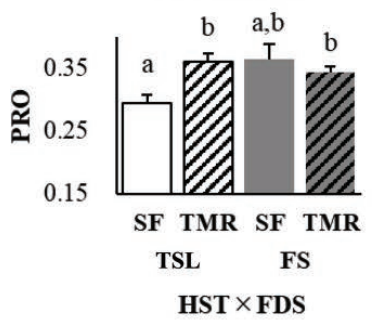

First lactation

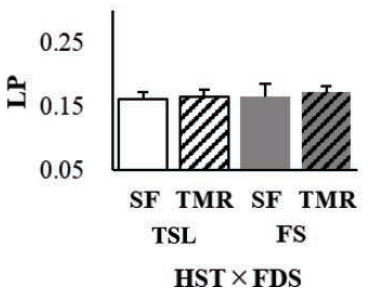

Second lactation

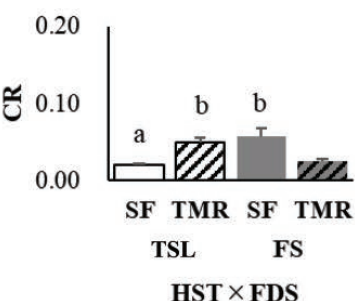

Second lactation

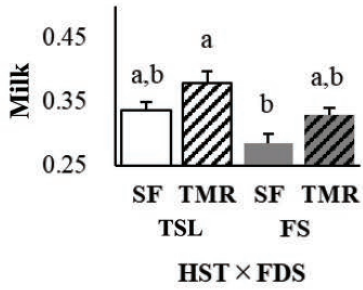

Second lactation

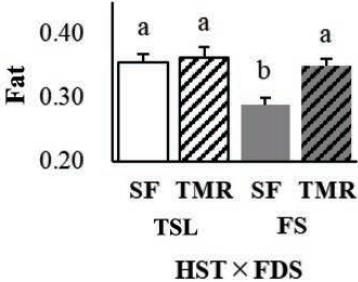

Second lactation

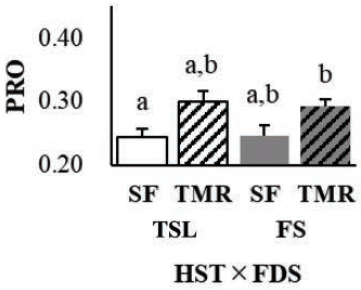

Second lactation

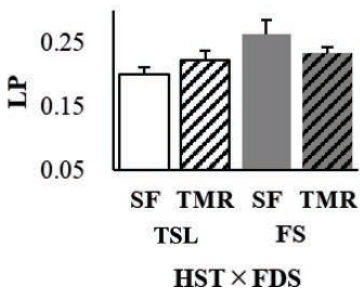

Third lactation

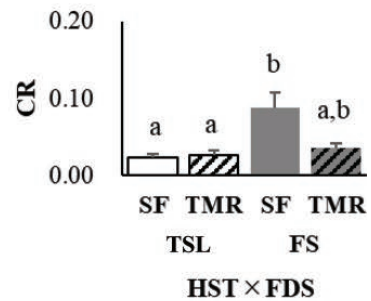

Third lactation

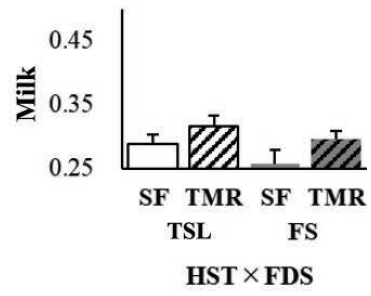

Third lactation

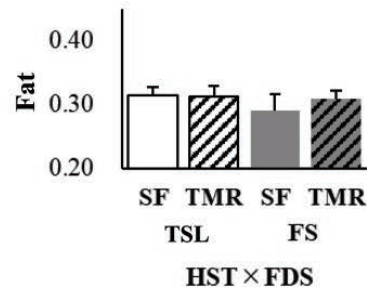

Third lactation

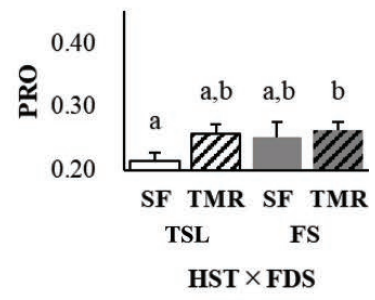

Third lactation

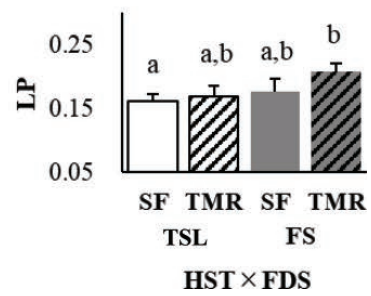

Figure 4. Posterior means of heritability for conception rate at first insemination (CR) and milk production traits in each housing type (HST) and feeding system (FDS) for the first 3 lactations. Within each figure, values with different letters $(\mathrm{a}, \mathrm{b})$ differ significantly $(P<0.05$ after Bonferroni correction). The production traits are cumulative milk, fat, and protein (PRO) yields within 305 DIM and lactation persistency (LP). LP $=100+$ milk yield at 240 DIM - milk yield at 60 DIM. The HST groups are tiestall barn (TSL) and freestall barn (FS). The FDS groups are separate feeding (SF), in which roughage and concentrates were weighed and fed separately, and feeding of TMR, in which roughage and concentrates were mixed before feeding. Error bars represent posterior SD. 
Table 4. Posterior means (posterior SD) of genetic correlations between conception rate at first insemination (CR) and milk production traits within each housing type (HST) for the first 3 lactations ${ }^{1}$

\begin{tabular}{|c|c|c|c|c|}
\hline \multirow[b]{2}{*}{ Item } & \multirow[b]{2}{*}{ Lactation } & \multicolumn{3}{|c|}{ HST } \\
\hline & & TSL & FS & GZ \\
\hline $\mathrm{CR}-$ milk & $\begin{array}{l}\text { First } \\
\text { Second } \\
\text { Third }\end{array}$ & $\begin{array}{l}-0.403(0.039)^{\mathrm{a}} \\
-0.414(0.049)^{\mathrm{a}} \\
-0.295(0.071)^{\mathrm{a}}\end{array}$ & $\begin{array}{l}-0.332(0.047)^{\mathrm{a}} \\
-0.350(0.063)^{\mathrm{ab}} \\
-0.270(0.086)^{\mathrm{a}}\end{array}$ & $\begin{array}{r}0.166(0.120)^{\mathrm{b}} \\
-0.122(0.090)^{\mathrm{b}} \\
0.101(0.129)^{\mathrm{b}}\end{array}$ \\
\hline CR-fat & $\begin{array}{l}\text { First } \\
\text { Second } \\
\text { Third }\end{array}$ & $\begin{array}{l}-0.340(0.039)^{\mathrm{a}} \\
-0.337(0.050) \\
-0.124(0.071)^{\mathrm{ab}}\end{array}$ & $\begin{array}{l}-0.257(0.050)^{\mathrm{ab}} \\
-0.218(0.062) \\
-0.214(0.085)^{\mathrm{a}}\end{array}$ & $\begin{array}{r}0.047(0.150)^{\mathrm{b}} \\
-0.046(0.174) \\
0.129(0.114)^{\mathrm{b}}\end{array}$ \\
\hline $\mathrm{CR}-\mathrm{PRO}$ & $\begin{array}{l}\text { First } \\
\text { Second } \\
\text { Third }\end{array}$ & $\begin{array}{l}-0.342(0.042)^{\mathrm{a}} \\
-0.357(0.054) \\
-0.164(0.069)^{\mathrm{ab}}\end{array}$ & $\begin{array}{l}-0.296(0.050)^{\mathrm{a}} \\
-0.249(0.065) \\
-0.204(0.091)^{\mathrm{a}}\end{array}$ & $\begin{array}{r}0.181(0.159)^{\mathrm{b}} \\
-0.215(0.116) \\
0.174(0.124)^{\mathrm{b}}\end{array}$ \\
\hline CR-LP & $\begin{array}{l}\text { First } \\
\text { Second } \\
\text { Third }\end{array}$ & $\begin{array}{l}-0.183(0.062) \\
-0.273(0.064)^{\mathrm{a}} \\
-0.343(0.072)\end{array}$ & $\begin{array}{l}-0.180(0.062) \\
-0.218(0.065)^{\mathrm{ab}} \\
-0.136(0.100)\end{array}$ & $\begin{array}{r}-0.314(0.096) \\
0.111(0.133)^{\mathrm{b}} \\
-0.155(0.141)\end{array}$ \\
\hline
\end{tabular}

$\overline{\mathrm{a}, \mathrm{b}}$ Within each row, values with different superscripts differ significantly $(P<0.05$ after Bonferroni correction $)$. ${ }^{1}$ The production traits are cumulative milk, fat, and protein (PRO) yields within 305 DIM and lactation persistency (LP). LP $=100+$ milk yield at 240 DIM - milk yield at 60 DIM. The HST groups are tiestall barn (TSL), freestall barn (FS), and management primarily by grazing on pasture (GZ).

$\times \mathrm{SF}-\mathrm{TSL} \times \mathrm{TMR}, \mathrm{TSL} \times \mathrm{SF}-\mathrm{FS} \times \mathrm{SF}$, and $\mathrm{TSL} \times$ TMR-FS $\times$ TMR in the first lactation. In the second lactation, the genetic correlation of LP for TSL $\times \mathrm{SF}-$ FS $\times$ SF was significantly smaller than those for TSL $\times \mathrm{SF}-\mathrm{TSL} \times \mathrm{TMR}$ and $\mathrm{TSL} \times \mathrm{SF}-\mathrm{FS} \times \mathrm{TMR}$, and in the third lactation the correlation of LP for TSL $\times$ TMR-FS $\times$ SF was significantly smaller than those for $\mathrm{TSL} \times \mathrm{SF}-\mathrm{TSL} \times \mathrm{TMR}$ and TSL $\times \mathrm{SF}-\mathrm{FS} \times \mathrm{TMR}$. For PROD other than LP, the genetic correlations of milk and PRO for TSL $\times$ SF-FS $\times$ SF were significantly smaller than those for TSL $\times$ SF-TSL $\times$ TMR and TSL $\times$ TMR-FS $\times$ TMR in the third lactation, respectively. The genetic correlation of fat for TSL $\times$ SF-FS $\times$ SF was significantly smaller than that for FS $\times \mathrm{SF}-\mathrm{FS} \times \mathrm{TMR}$ in the second lactation.

\section{DISCUSSION}

Our heritability estimates for CR were higher in GZ systems than in TSL and FS systems in all lactations (Figure 3). Moreover, our genetic correlation estimates of CR between GZ and the other HST were weaker than those between TSL and FS in all lactations (Table 6). Boettcher et al. (2003) reported that the heritability of

Table 5. Posterior means (posterior SD) of genetic correlations between conception rate at first insemination (CR) and milk production traits within each housing type (HST) and feeding system (FDS) for the first 3 lactations $^{1}$

\begin{tabular}{llllll}
\hline \multirow{2}{*}{ Item } & \multicolumn{4}{c}{ HST $\times$ FDS } \\
\cline { 3 - 6 } & Lactation & \multicolumn{1}{c}{ TSL $\times$ SF } & TSL $\times$ TMR & FS $\times$ SF & FS $\times$ TMR \\
\hline CR-milk & First & $-0.499(0.047)^{\mathrm{a}}$ & $-0.297(0.059)^{\mathrm{b}}$ & $-0.307(0.079)^{\mathrm{ab}}$ & $-0.320(0.044)^{\mathrm{b}}$ \\
& Second & $-0.420(0.073)$ & $-0.473(0.063)$ & $-0.199(0.103)$ & $-0.257(0.065)$ \\
& Third & $-0.257(0.094)$ & $-0.296(0.097)$ & $-0.161(0.109)$ & $-0.241(0.079)$ \\
CR-fat & First & $-0.479(0.046)^{\mathrm{a}}$ & $-0.198(0.065)^{\mathrm{b}}$ & $-0.189(0.101)^{\mathrm{ab}}$ & $-0.230(0.051)^{\mathrm{b}}$ \\
& Second & $-0.405(0.074)$ & $-0.230(0.070)$ & $-0.133(0.126)$ & $-0.179(0.067)$ \\
& Third & $-0.156(0.100)$ & $-0.065(0.116)$ & $-0.100(0.112)$ & $-0.179(0.071)$ \\
CR-PRO & First & $-0.470(0.041)^{\mathrm{a}}$ & $-0.190(0.066)^{\mathrm{b}}$ & $-0.290(0.075)^{\mathrm{ab}}$ & $-0.283(0.047)^{\mathrm{b}}$ \\
& Second & $-0.311(0.092)^{\mathrm{ab}}$ & $-0.440(0.067)^{\mathrm{a}}$ & $-0.094(0.092)^{\mathrm{b}}$ & $-0.179(0.066)^{\mathrm{b}}$ \\
& Third & $-0.126(0.100)$ & $-0.154(0.108)$ & $-0.174(0.118)$ & $-0.200(0.075)$ \\
CR-LP & First & $-0.285(0.060)$ & $-0.099(0.085)$ & $-0.003(0.103)$ & $-0.273(0.062)$ \\
& Second & $-0.328(0.075)$ & $-0.207(0.084)$ & $-0.100(0.101)$ & $-0.172(0.067)$ \\
& Third & $-0.347(0.106)$ & $-0.309(0.085)$ & $-0.080(0.119)$ & $-0.126(0.085)$ \\
\hline
\end{tabular}

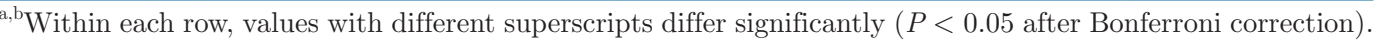
${ }^{1}$ The production traits are cumulative milk, fat, and protein (PRO) yields within 305 DIM and lactation persistency (LP). LP $=100+$ milk yield at 240 DIM - milk yield at 60 DIM. The HST groups are tiestall barn (TSL) and freestall barn (FS). The FDS groups are separate feeding (SF), in which roughage and concentrates were weighed and fed separately, and feeding of TMR, in which roughage and concentrates were mixed before feeding. 
calving interval was higher for grazing systems than for conventional management systems and that the genetic correlation between these systems was relatively weak (0.64). These previous results suggest that the genotypic effects for CR in GZ differed from those in TSL and FS barns. In our current data set, the averages of milk were lowest in the GZ system in all lactations. These differences in milk production level between pasturebased and indoor FDS are in line with previous findings (e.g., Fontaneli et al., 2005; O'Callaghan et al., 2016). Some studies have shown that genetic correlations for calving interval (Haile-Mariam et al., 2008; Strandberg et al., 2009) or CR (Yamazaki et al., 2019) between herds with low and high milk production levels are relatively weak. These results suggest that a production system that decreases milk production influences genotypic effects on the fertility of lactating cows.

We found that the genetic correlations between CR and PROD were weak and negative in TSL and FS, and most of those in the GZ system were even weaker than those in TSL or FS systems (Table 4). These values in TSL and FS systems are consistent with previous findings (e.g., Kadarmideen et al., 2003; Abe et al., 2009; Yamazaki et al., 2014). The genetic correlations in GZ indicate that the pleiotropic expression of genes for fertility and milk production in GZ differed from those in TSL and FS barns. Cummins et al. (2012) reported that cows with superior EBV for calving interval had significantly greater daily milk yields in a pasture-based system than those with inferior EBV for calving interval.
In the comparison among the 4 HST $\times$ FDS $($ TSL or FS $\times \mathrm{SF}$ or TMR), our heritability estimates for $\mathrm{CR}$ in FS $\times \mathrm{SF}$ systems were higher than those in the other HST $\times$ FDS systems in all lactations (Figure 4). Moreover, our genetic correlation estimates of CR between FS $\times \mathrm{SF}$ and all other HST $\times$ FDS were weaker than those across the other HST $\times$ FDS pairs in the same lactation (Table 7). These differences of genetic parameter estimates for $\mathrm{CR}$ between $\mathrm{FS} \times \mathrm{SF}$ and the other HST $\times$ FDS were the same as those between GZ and the other HST systems. The FS $\times$ SF system, in which roughage is fed ad libitum and supplemental concentrate is fed according to the individual cow's milk production level, is similar to the GZ system, in which fresh grass and supplemental concentrate are fed separately. These FDS may affect genotypic effects in terms of a cow's ability to conceive.

We determined the EBV of CR for each HST or HST $\times$ FDS in the first lactation and then plotted the genetic trends for cows with records (Figure 5). The genetic trends for GZ, TSL $\times$ TMR, and FS $\times \mathrm{SF}$ differed from those for the other production systems; in particular, the average EBV of CR for GZ were lower than those for the other systems. These differences indicate that the genetic selection responses for fertility differ among HST and FDS, especially between GZ and the other HST.

Calculating accurate EBV for CR of bulls in grazing herds by using their daughters' records is difficult because both the number of farms managed by grazing and of cows managed by grazing are small in Japan.

Table 6. Posterior means (posterior SD) of genetic correlations for conception rate at first insemination (CR) and milk production traits across housing types (HST) for the first 3 lactations ${ }^{1}$

\begin{tabular}{|c|c|c|c|c|}
\hline \multirow[b]{2}{*}{ Item } & \multirow[b]{2}{*}{ Lactation } & \multicolumn{3}{|c|}{ Genetic correlation between HST } \\
\hline & & TSL-FS & TSL-GZ & FS-GZ \\
\hline \multirow[t]{3}{*}{$\mathrm{CR}$} & First & $0.939(0.011)^{\mathrm{a}}$ & $0.582(0.138)^{\mathrm{b}}$ & $0.369(0.136)^{b}$ \\
\hline & Second & $0.917(0.020)^{\mathrm{a}}$ & $0.625(0.136)^{\mathrm{ab}}$ & $0.416(0.113)^{\mathrm{b}}$ \\
\hline & Third & $0.786(0.049)^{\mathrm{a}}$ & $0.431(0.090)^{\mathrm{b}}$ & $0.656(0.068)^{\mathrm{ab}}$ \\
\hline \multirow[t]{3}{*}{ Milk } & First & $0.967(0.005)$ & $0.971(0.009)$ & $0.923(0.021)$ \\
\hline & Second & $0.954(0.011)^{\mathrm{a}}$ & $0.892(0.025)^{\mathrm{ab}}$ & $0.853(0.040)^{\mathrm{b}}$ \\
\hline & Third & $0.971(0.007)$ & $0.906(0.046)$ & $0.797(0.087)$ \\
\hline \multirow[t]{3}{*}{ Fat } & First & $0.959(0.007)$ & $0.959(0.008)$ & $0.926(0.019)$ \\
\hline & Second & $0.956(0.010)$ & $0.874(0.051)$ & $0.883(0.040)$ \\
\hline & Third & $0.975(0.007)^{\mathrm{a}}$ & $0.875(0.104)^{\mathrm{ab}}$ & $0.773(0.063)^{b}$ \\
\hline \multirow[t]{3}{*}{ PRO } & First & $0.962(0.006)^{\mathrm{a}}$ & $0.949(0.015)^{\mathrm{ab}}$ & $0.881(0.032)^{b}$ \\
\hline & Second & $0.936(0.016)$ & $0.843(0.050)$ & $0.810(0.066)$ \\
\hline & Third & $0.971(0.010)^{\mathrm{a}}$ & $0.830(0.067)^{\mathrm{ab}}$ & $0.689(0.115)^{\mathrm{b}}$ \\
\hline \multirow[t]{3}{*}{ LP } & First & $0.923(0.021)$ & $0.933(0.019)$ & $0.854(0.049)$ \\
\hline & Second & $0.964(0.009)^{\mathrm{a}}$ & $0.669(0.084)^{\mathrm{b}}$ & $0.498(0.109)^{\mathrm{b}}$ \\
\hline & Third & $0.944(0.016)^{\mathrm{a}}$ & $0.836(0.071)^{\mathrm{ab}}$ & $0.652(0.115)^{\mathrm{b}}$ \\
\hline
\end{tabular}

\footnotetext{
${ }^{\mathrm{a}, \mathrm{b}}$ Within each row, values with different superscripts differ significantly $(P<0.05$ after Bonferroni correction). ${ }^{1}$ The production traits are cumulative milk, fat, and protein (PRO) yields within 305 DIM and lactation persistency (LP). LP $=100+$ milk yield at 240 DIM - milk yield at 60 DIM. The HST groups are tiestall barn (TSL), freestall barn (FS), and management primarily by grazing on pasture (GZ).
} 


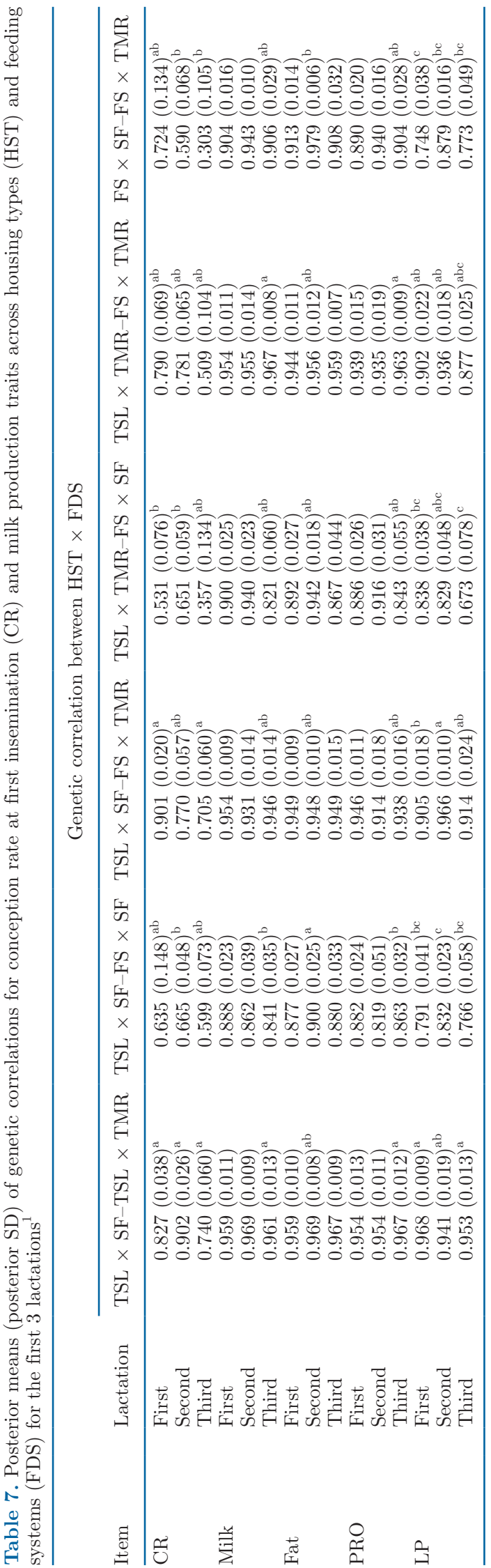

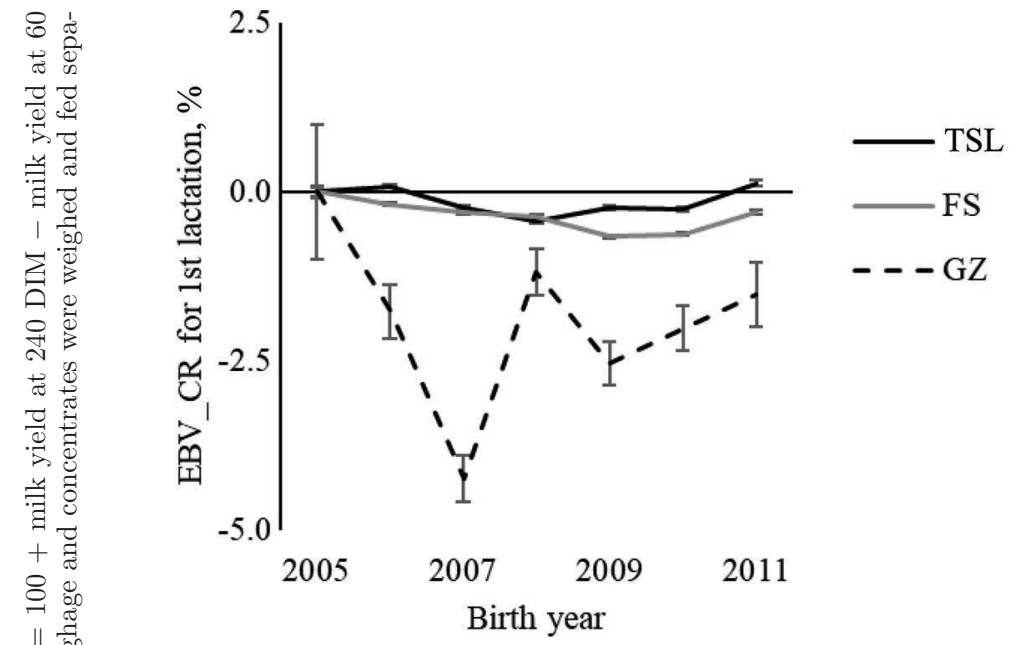

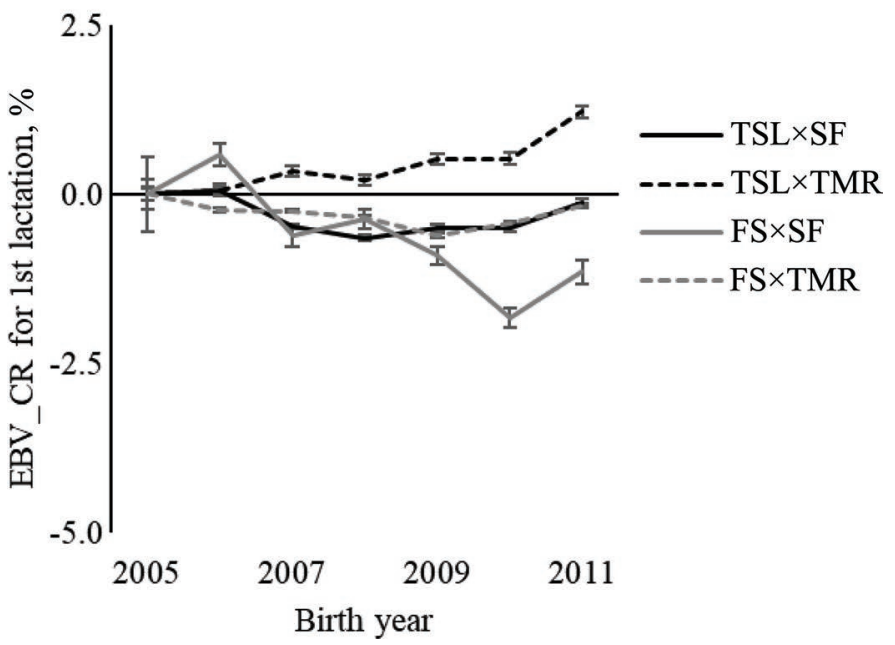

Figure 5. Averages of EBV of conception rate at first insemination (CR) by year of birth for first-lactation cows with records for each housing type (HST) and feeding system (FDS). The HST groups are tiestall barn (TSL), freestall barn (FS), and management primarily by grazing on pasture (GZ). The FDS groups are separate feeding (SF), in which roughage and concentrates were weighed and fed separately, and feeding of TMR, in which roughage and concentrates were mixed before feeding. Error bars represent SE. Values shown for each HST or HST $\times$ FDS are deviations from the averages in cows born in 2005 . The EBV were estimated by using an HST $\times$ one-trait or HST $\times$ FDS $\times$ one-trait animal model and a preconditioned conjugate gradient algorithm with iteration on data in a program developed by the National Livestock Breeding Center (Nishigo-mura, Japan) for national evaluation in Japan.

We found that the genetic correlations between CR and PROD in GZ were weaker than those for the other production systems. These findings suggest that the undesirable correlated effects on fertility that result from improving PROD are smaller for grazing herds than for other production systems. This result also implies that traits that correlate favorably with fertility differ among production systems. Providing the information 
regarding genetic correlations between fertility and other traits and regarding traits that correlate favorably with fertility in each production system would help farmers in choosing appropriate bulls to improve fertility and productivity of heifers simultaneously in their farming systems. The indexes that uses the correlations and economic weights appropriate for each production system to utilize the differences reported should be developed.

In conclusion, we examined the genetic relationships among female fertility traits and milk PROD during the first 3 lactations of Holstein cows, in regard to the HST and FDS for each herd. The heritability estimates for conception rate were higher for GZ cows than for those housed in TSL or FS barns, and the genetic correlations for conception rate between GZ and TSL or FS barns were weaker than those between TSL and FS barns. In the comparison among 4 housing types $\times$ FDS (TSL or FS barns $\times$ SF or TMR) except GZ, the heritability estimates for conception rate in the FS $\times \mathrm{SF}$ system were higher than those for all other systems, and the genetic correlations for conception rate between the FS $\times \mathrm{SF}$ system and other systems were relatively weak. Moreover, the genetic correlations between conception rate and milk PROD were weaker for GZ cows than for those housed in TSL and FS barns. Our findings indicate that choices regarding housing management and FDS for each herd affect genotypic effects in terms of cows' ability to conceive; in particular, gene expression in GZ differs from that in the other housing systems. This finding suggests that the bulls most appropriate for improving cows' ability to conceive differ between GZ farms and all other farming systems that we evaluated.

\section{ACKNOWLEDGMENTS}

This work was supported by a grant from the Ministry of Agriculture, Forestry, and Fisheries, Tokyo, Japan (Development of Breeding Technology for Animal Life Production). The authors have no conflicts of interest to declare.

\section{REFERENCES}

Abe, H., Y. Masuda, and M. Suzuki. 2009. Relationships between reproductive traits of heifers and cows and yield traits for Holsteins in Japan. J. Dairy Sci. 92:4055-4062. https://doi.org/10.3168/jds 2008-1896.

Boettcher, P. J., J. Fatehi, and M. M. Schutz. 2003. Genotype $\times$ environment interactions in conventional versus pasture-based dairies in Canada. J. Dairy Sci. 86:383-389. https://doi.org/10.3168/jds .S0022-0302(03)73617-0.

Calus, M. P. L., J. J. Windig, and R. F. Veerkamp. 2005. Associations among descriptors of herd management and phenotypic and genetic levels of health and fertility. J. Dairy Sci. 88:2178-2189. https://doi.org/10.3168/jds.S0022-0302(05)72893-9.

Cummins, S. B., P. Lonergan, A. C. O. Evans, D. P. Berry, R. D. Evans, and S. T. Butler. 2012. Genetic merit for fertility traits in Holstein cows: I. Production characteristics and reproductive efficiency in a pasture-based system. J. Dairy Sci. 95:1310-1322. https://doi.org/10.3168/jds.2011-4742.

Fontaneli, R. S., L. E. Sollenberger, R. C. Littell, and C. R. Staples. 2005. Performance of lactating dairy cows managed on pasturebased or in freestall barn-feeding systems. J. Dairy Sci. 88:12641276. https://doi.org/10.3168/jds.S0022-0302(05)72793-4.

Haile-Mariam, M., M. J. Carrick, and M. E. Goddard. 2008. Genotype by environment interaction for fertility, survival, and milk production traits in Australian dairy cattle. J. Dairy Sci. 91:4840-4853. https://doi.org/10.3168/jds.2008-1084.

Ismael, A., E. Strandberg, B. Berglund, M. Kargo, A. Fogh, and P. Løvendahl. 2016. Genotype by environment interaction for activity-based estrus traits in relation to production level for Danish Holstein. J. Dairy Sci. 99:9834-9844. https://doi.org/10.3168/jds 2016-11446.

Kadarmideen, H. N., R. Thompson, M. P. Coffey, and M. A. Kossaibati. 2003. Genetic parameters and evaluations from single- and multiple-trait analysis of dairy cow fertility and milk production. Livest. Prod. Sci. 81:183-195. https://doi.org/10.1016/S0301 -6226(02)00274-9.

Liu, A., G. Su, J. Höglund, Z. Zhang, J. Thomasen, I. Christiansen, Y. Wang, and M. Kargo. 2019. Genotype by environment interaction for female fertility traits under conventional and organic production systems in Danish Holsteins. J. Dairy Sci. 102:8134-8147. https://doi.org/10.3168/jds.2018-15482.

Misztal, I. 2008. Reliable computing in estimation of variance components. J. Anim. Breed. Genet. 125:363-370. https://doi.org/10 $.1111 / \mathrm{j} .1439-0388.2008 .00774 . x$.

O'Callaghan, T. F., D. Hennessy, S. McAuliffe, K. N. Kilcawley, M. O'Donovan, P. Dillon, R. P. Ross, and C. Stanton. 2016. Effect of pasture versus indoor feeding systems on raw milk composition and quality over an entire lactation. J. Dairy Sci. 99:9424-9440. https://doi.org/10.3168/jds.2016-10985.

Schaeffer, L. R., and J. Jamrozik. 1996. Multiple-trait prediction of lactation yields for dairy cows. J. Dairy Sci. 79:2044-2055. https:/ /doi.org/10.3168/jds.S0022-0302(96)76578-5.

Strandberg, E., S. Brotherstone, E. Wall, and M. P. Coffey. 2009. Genotype by environment interaction for first-lactation female fertility traits in UK dairy cattle. J. Dairy Sci. 92:3437-3446. https:/ /doi.org/10.3168/jds.2008-1844.

Wilmink, J. B. M. 1987. Adjustment of test-day milk, fat and protein yield for age, season and stage of lactation. Livest. Prod. Sci. 16:335-348. https://doi.org/10.1016/0301-6226(87)90003-0.

Yamazaki, T., K. Hagiya, H. Takeda, S. Yamaguchi, T. Osawa, and Y. Nagamine. 2014. Genetic correlations among female fertility, 305day milk yield and persistency during the first three lactations of Japanese Holstein cows. Livest. Sci. 168:26-31. https://doi.org/10 $.1016 /$ j.livsci.2014.08.005.

Yamazaki, T., H. Takeda, T. Osawa, S. Yamaguchi, and K. Hagiya. 2019. Genetic correlations among fertility traits and lactation persistency within and across Holstein herds with different milk production during the first three lactations. Livest. Sci. 219:97-103. https://doi.org/10.1016/j.livsci.2018.12.001.

\section{ORCIDS}

T. Yamazaki (® https://orcid.org/0000-0002-7347-3509

S. Yamaguchi @ https://orcid.org/0000-0001-9087-450X

H. Takeda ๑ https://orcid.org/0000-0003-4104-4272

T. Osawa (๑) https://orcid.org/0000-0003-2852-292X

K. Hagiya ๑ https://orcid.org/0000-0001-9869-9400 